\title{
Clinical and molecular cytogenetic (FISH) diagnosis of Williams syndrome
}

\author{
C M Brewer, N Morrison, J L Tolmie
}

\begin{abstract}
Sixteen children and adolescents with a firm clinical diagnosis of Williams syndrome were investigated with the chromosome fluorescence in situ hybridisation (FISH) technique employing the elastin gene probe. In each case there was a fluorescent signal on one chromosome 7 homologue only, indicating elastin gene deletion. No deletion was demonstrated in another child in whom an earlier diagnosis of Williams syndrome was judged doubtful at review. Firm clinical diagnosis correlates with elastin gene deletion in 16/16 cases of Williams syndrome and detection of such hemizygosity by FISH constitutes a useful confirmatory diagnostic test. (Arch Dis Child 1996; 74: 59-61)
\end{abstract}

Keywords: Williams syndrome, elastin gene, fluorescence in situ hybridisation (FISH), chromosome microdeletion.

Williams syndrome comprises supravalvular aortic stenosis, intellectual disability, and mild but characteristic facial dysmorphism (fig 1). ${ }^{1-4} \mathrm{~A}$ similar facial appearance is present in idiopathic infantile hypercalcaemia 56 and it is now generally recognised that these conditions are the same, ${ }^{7}$ with neither cardiac defect nor hypercalcaemia present in every case. Variable clinical expression means that diagnosis may be difficult or delayed, the average age at diagnosis in one series being 6.4 years. ${ }^{4}$ A microdeletion involving the elastin gene at chromosome $7 q_{11.23}$ in Williams syndrome has been reported ${ }^{8}$ and recent work has demonstrated that elastin gene deletion occurs in the majority of affected individuals. ${ }^{9-11}$ In this study, we sought to determine the frequency of elastin
Duncan Guthrie Genetics, Royal Hospital for Sick Children, Glasgow C M Brewer N Morrison J L Tolmie

Correspondence to: Dr C M Brewer, Departmen of Clinical Genetics, Western General Hospital, Crewe Road, Edinburgh EH4 2XU. Accepted 11 August 1995 gene deletion in a group of patients with a firm clinical diagnosis of Williams syndrome in the west of Scotland.

\section{Patients and methods}

Seventeen patients believed to have Williams syndrome, whose families were referred to the West of Scotland Genetics Service during a 15 year period, were recalled and reviewed. There were six girls and 11 boys with a mean age at review of 7 years (range 18 months -20 years). The mean age at diagnosis was 2 years 9 months (range 4 months -7 years). Clinical features are tabulated and there was agreement with the original clinical diagnosis in all but one case.

For fluorescence in situ hybridisation (FISH) studies, lymphocytes were cultured using standard methods before hybridisation with the elastin gene probe (Oncor) performed according to manufacturer's instructions.

\section{Results}

Conventional cytogenetic studies (Giemsa banding) were normal except in case 12 who had a small, de novo marker chromosome, shown by chromosome painting studies to be

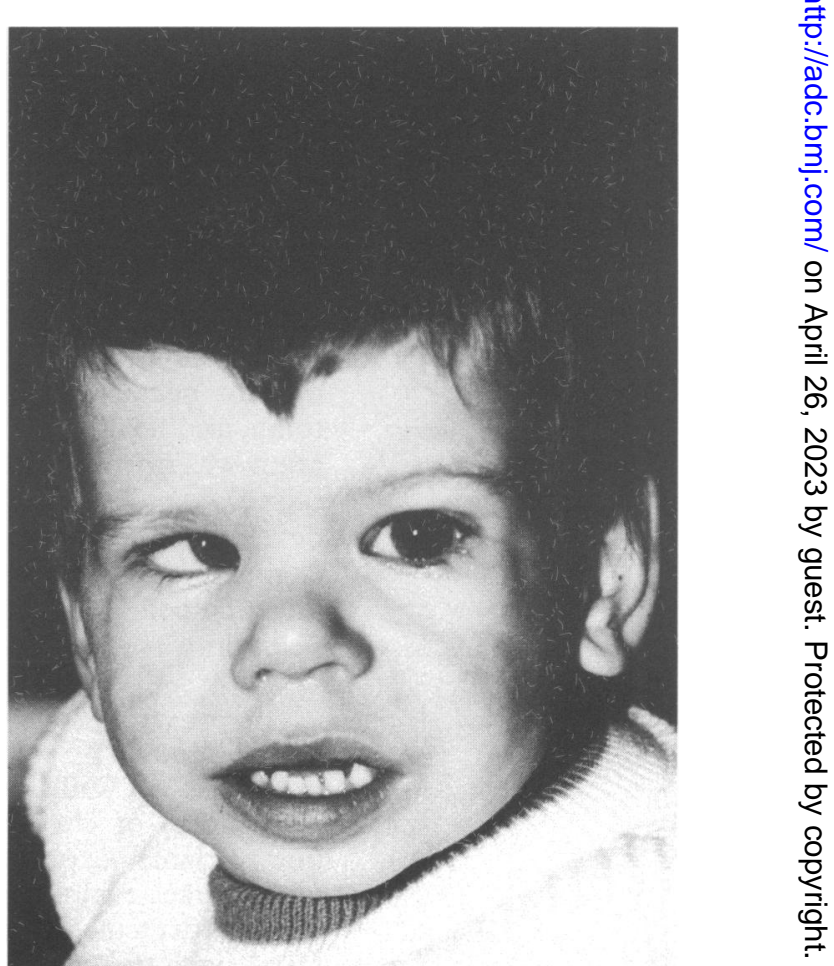

Figure 1 Case 5 has typical facial appearance of Williams syndrome with temporal narrowing, full cheeks, periorbital puffiness, long philtrum, up-turned nose, thick lower lip, and strabismus.
Absent $(n=1)$ Diagnosis of William syndrome judged 0

0 echocardiogram
Documented hypercalcaemia Developmental delay Hernia

Failure to thrive 


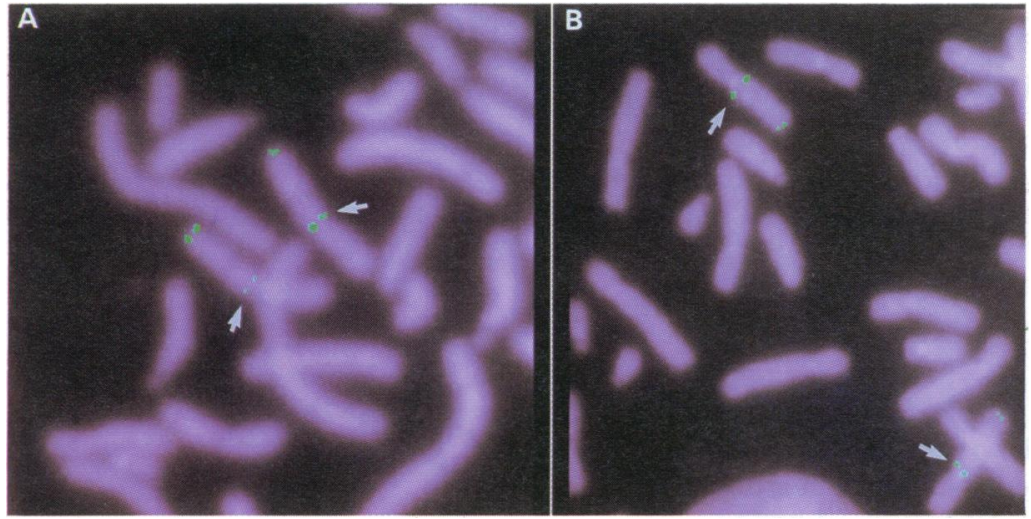

Figure 2 Metaphase spreads after FISH with elastin gene probe showing (A) one normal hybridisation signal with weaker signal on the other chromosome 7 homologue (arrowed) in a child with Williams syndrome, (B) two normal signals. The signals appear as double images because there is hybridisation to each of the two sister chromatids. The signal at $7 q 36$ results from cohybridisation to chromosome 7 control probe D7S427.

derived from chromosome 6 . In 16 cases hybridisation signals were detected on only one chromosome 7 homologue, indicating deletion of the elastin gene. However, in four of these cases, although there was unambiguous deletion of the elastin gene in the majority of cells, a weak second hybridisation signal was seen in $2 / 15,2 / 19,1 / 11$, and $2 / 22$ cells examined, respectively (fig 2 ). The quality of these signals was clearly different from that of controls and of normal homologues. It is perhaps notable that three of these four children had milder clinical features than the rest of the group. Case 4 has normal growth and development at 18 months of age despite typical facies, supravalvular aortic stenosis, and hypercalcaemia. Case 8 has only mild intellectual impairment but typical facies and a cardiac defect. Case 13 has moderate intellectual impairment, strabismus, inguinal hernias, and hypercalcaemia but a normal echocardiogram and a less characteristic facial appearance (fig 3). Case 14 has dysplastic renal disease which was detected prenatally. Williams syndrome was diagnosed at the age of 4 years as a result of his characteristic facial appearance and developmental delay; however, he has neither hypercalcaemia nor a heart defect.

One child (case 15, fig 4) was thought to have Williams syndrome at the age of 6 months because of his facial features, hypotonia, and feeding difficulties. An echocardiogram was normal and serum calcium was not raised. At 18 months he had moderate developmental delay, but his appearance had changed and the diagnosis was considered improbable. He does not have elastin gene deletion.

\section{Discussion}

Diagnosis of Williams syndrome relies upon recognition of characteristic clinical findings but variable expression of the phenotype often makes evaluation difficult. In particular, cardiac defects are not always present, the facial signs may be subtle, especially in young children, and hypercalcaemia may be absent. Previous attempts to provide more objective methods to assist diagnosis have included

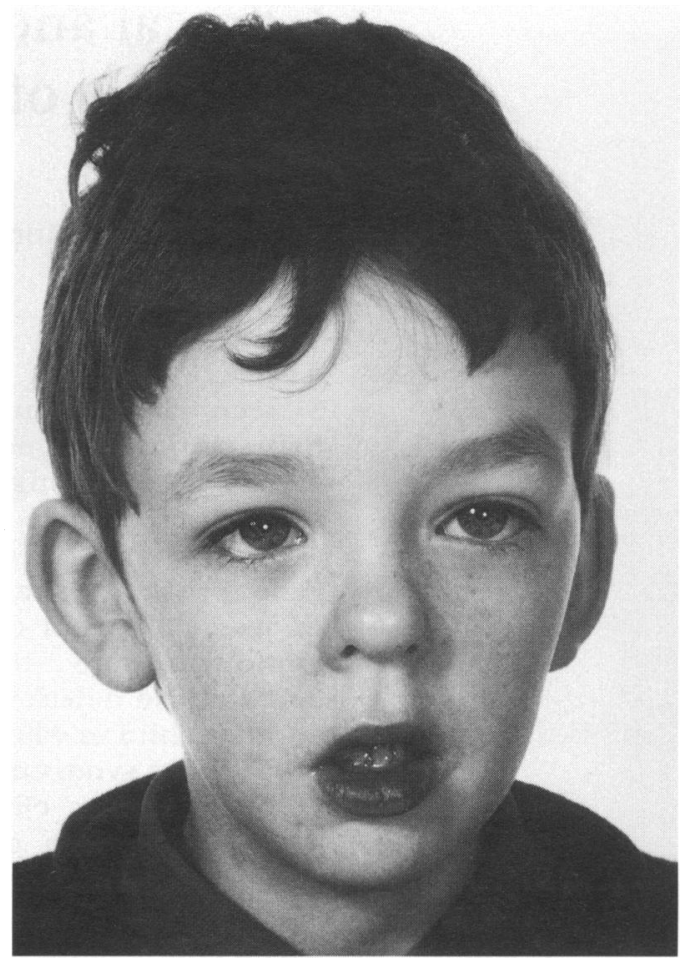

Figure 3 Case 13 has some atypical facial features of Williams syndrome: long, narrow face and prominent ears. He has deletion of one elastin gene in 10/11 cells, but a weak second hybridisation signal in $1 / 11$ cells.

numerical taxonomy, weighted assessment of 50 features such as stellate irides, hernias, and hoarse voice ${ }^{12}$ and radiological analysis of the metacarpophalangeal pattern. ${ }^{13}$ These techniques are often difficult to use in practice and have inherent drawbacks including incomplete sensitivity and specificity.

Genetic linkage evidence of elastin gene involvement in isolated supravalvular aortic stenosis ${ }^{14}$ led to the proposal that the variable phenotype of Williams syndrome is caused by a submicroscopic chromosome aberration that deletes the elastin gene as well as unknown neighbouring genes. ${ }^{8}$ In the light of this suggestion, our novel and unexpected finding in four of the cases of a weak second signal in fewer than $10 \%$ of cells examined is notable. Two of these four cases (4 and 8) have less marked neurodevelopmental problems, and two (13 and 14) have normal echocardiograms despite cardiac murmurs. Case 13 has a less typical facial appearance than the other children. Interestingly, three of the four cases have normal growth. One has renal dysplasia. Variability of the Williams syndrome phenotype may thus correlate with the extent of the molecular cytogenetic deletion. Variation in the size of deletions has been demonstrated using microsatellite DNA markers and polymerase chain reaction techniques, ${ }^{11}$ but correlations with clinical features have yet to be made. Recent studies have indicated prevalences of elastin gene deletion in Williams syndrome ranging from $75 \%$ to $100 \% .^{9-11} 15-19$ This variation may reflect differences in diagnostic criteria as well as the subjective and sometimes incorrect appreciation of the facial and neurodevelopmental phenotype (as we discovered in case 



Figure 4 (A) Case 15 displayed facial features of Williams syndrome at age 6 months but by 18 months (B) his appearance had changed and the diagnosis was later judged improbable. He does not have elastin gene deletion.

15). However, four cases with no deletions were found in a recent study of 44 individuals with typical features ${ }^{9}$ and in another series four out of 114 cases of 'classic' Williams syndrome did not have deletions. ${ }^{10}$ Conversely, a much lower frequency of elastin gene hemizygosity was seen in individuals where the diagnosis of Williams syndrome was uncertain. Absence of elastin gene deletion in typically affected individuals implies that the classic phenotype can rarely arise by alternative genetic mechanisms.

The chromosome 7 microdeletion arises in most cases presumably through fresh mutation, ${ }^{151819}$ allowing parents to be reassured of the low recurrence risk for siblings. Nevertheless, four families in which vertical transmission of Williams syndrome occurred have been reported, and diagnosis of an affected parent was made only after recognition of the condition in the child. ${ }^{20} 21$ Such reports of autosomal dominant inheritance are rare, probably because the great majority of adults with Williams syndrome do not live independently in the community and therefore they are unlikely to reproduce. ${ }^{4}$ The $1: 2$ risk of recurrence in offspring of affected individuals clearly has implications for young people with Williams syndrome and for their families and professionals involved in their care.

In this investigation, we demonstrated excellent agreement between firm clinical diagnosis of Williams syndrome and elastin gene hemizygosity and therefore we suggest that the FISH technique to detect elastin gene deletion is adopted as a confirmatory diagnostic test against which the spectrum of clinical features associated with Williams syndrome might be established. If no elastin gene abnormality is detected, careful clinical re-evaluation is necessary, and a diagnosis of Williams syndrome is unlikely in all but a small number of individuals with classical features.

We thank Dr W Doig and Dr A Houston for referral of patients; Mr J Colgan for lymphocyte cultures; and Dr E Boyd and Mr $M$ Mohaddes for assistance with illustrations of FISH results.
1 Williams JCP, Barratt-Boyes BG, Lowe JB. Supravalvular aortic stenosis. Circulation 1961; 24: 1311-8.

2 Beuren AJ, Apitz J, Harmjanz D. Supravalvular aortic stenosis in association with mental retardation and certain ftenosis in association with mental retardation and

3 Burn J. Williams syndrome. $\mathcal{f}$ Med Genet 1986; 23: 389-95.

4 Morris CA, Demsey SA, Leonard CO, Dilts C, Blackburn BL. Natural history of Williams syndrome: physical characteristics. $\mathcal{F}$ Pediatr 1988; 113: 318-26.

5 Black JA, Bonham Carter RE. Association between aortic stenosis and facies of infantile of severe infantile hypercalcaemia. Lancet 1963; ii: 745-9.

6 Joseph MC, Parrott D. Severe infantile hypercalcaemia with special reference to the facies. Arch Dis Child 1958; 33: 385-95.

7 Martin NDT, Snodgrass GJAI, Cohen RD. Idiopathic infantile hypercalcaemia - a continuing enigma. Arch Dis Child 1984; 59: 605-13.

8 Ewart AK, Morris CA, Atkinson D, et al. Hemizygosity at the elastin locus in a developmental disorder, Williams syndrome. Nature Genetics 1993; 5: 11-6.

9 Nickerson E, Greenberg F, Keating MT, McCaskill C, Shaffer LG. Deletions of the elastin gene at $7 \mathrm{q} 11.23$ occur in $\sim 90 \%$ of patients with williams syndrome. Am f Hum Genet 1995; 56: 1156-61.

10 Lowery MC, Morris CA, Ewart A, et al. Strong correlation of elastin deletions, detected by FISH, with Williams syndrome: evaluation of 235 patients. Am f Hum Genet 1995; 57: 49-53.

11 Gilbert-Dussardier B, Bonneau D, Gigarel N, et al. A novel microsatellite DNA marker at locus D7S1870 detects hemizygosity in $75 \%$ of patients with Williams syndrome [Letter]. Am f Hum Genet 1995; 56: 542-4.

12 Preus $M$. The Williams syndrome: objective definition and diagnosis. Clin Genet 1984; 25: 422-8.

13 Burns MA, McLeod DR, Linton LR, Butler MG. Metacarpophalangeal pattern profile analysis in Williams Metacarpophalangeal pattern profile analysis

14 Ewart AK, Morris CA, Atkinson D, et al. A human vascular disorder, supravalvular aortic stenosis, maps to chromodisorder, supravalvular aortic stenosis, maps to chrom
some 7. Proc Natl Acad Sci USA 1993; 90: 3226-30.

15 Perez Jurado LA, Peoples R, Kaplan P, Mariman ECM, Francke U. Deletions and candidate genes in Williams syndrome. Am f Hum Genet Suppl 1994; 55: A42 (No 214)

16 Lowery M, Brothman L, Ewart A, et al. Application of ELN cosmid probes using fluorescence in situ hybridisation (FISH) towards a clinical diagnostic test for Williams syndrome. Am $₹$ Hum Genet Suppl 1994; 55: A38 (No 194).

17 Morimoto Y, Kuwano A, Kuwajima K, et al. Hemizygosity at the elastin locus and clinical features of Williams syndrome. Am f Hum Genet Suppl 1994; 55: A362 (No 2126).

18 Morris CA, Ewart AK, Sternes K, et al. Molecular and cytogenetic studies of 55 patients diagnosed with Williams syndrome. Am f Hum Genet Suppl 1994; 55: A88 (No 493).

19 Greenberg F, Nickerson E, McCaskill C, Keating $M$, Shaffer LG. Deletions of the elastin gene in Williams syndrome. Am f Hum Genet Suppl 1994; 55: A41 (No 213)

20 Morris CA, Thomas IT, Greenberg F. Williams syndrome: autosomal dominant inheritance. Am $\mathcal{F}$ Med Genet 1993; 47: 478-81.

21 Sadler LS, Robinson LK, Verdaasdonk KR, Gingell R. The Williams syndrome: evidence for possible autosomal dominant inheritance. Am $\mathcal{F}$ Med Genet 1993; 47: 468-70. 